\title{
EMPLOYEE VALUE PROPOSITION AND ITS INFLUENCE ON INSTITUTIONAL IMAGE WITH REFERENCE TO B SCHOOLS
}

\author{
Dr. MANJUNATH. $\mathrm{S}^{1} \&$ CHAITRA ${ }^{2}$ \\ ${ }^{I}$ Associate Professor, School of Research \& Innovation, CMR University, Bengaluru, India \\ ${ }^{2}$ Scholar, ISBR (Mysore University), Assistant Professor IIBS, Bengaluru, India
}

\begin{abstract}
Competitiveness is the crux of being successful, it's not just applicable to employees seeking for opportunity to be in the right job but it has proven to be quite important for the employer as well to be competitive in terms of their offering for present and potential manpower in the organization. Shortage of skill work force, increasing employee turnover has made the organization to be hell bent about giving a loud thought to the importance of retaining and attracting talented employees through their unique selling proposition of providing the right proportion of facilities and privileges expected by competitive workforce in job market. Employer value proposition is a glimpse of various aspects associated with the employers which could be in the form of work culture, superior subordinate relationship, competitive compensation and rewards, training and development, career development opportunities and much more. As employers make huge investment in their offering to motivate employees, they presume their EVP to be the best in the industry but that may not be the same from an existing employee or potential employee's perspective. A turbulent change in the industry not only enforces employees to sharpen their skills but also proves to be a challenge for an employer in terms of providing an accommodative environment for these talented work forces. It is important for the $B$ Schools to be keep themselves abreast about the changing trends prevailing in the industry in terms EVP and also understand the influence of EVP on institutional image. Changing dynamics in the business has its influence on every industry and education sector is no exception to the same. Research emphasizes on understanding the influence of Employee value proposition on building institutional image in order to attract and retain talented workforce. Factors such as nature of work, compensation, training and development, work environment and career growth, relationship with supervisor are considered for the study, a sample size of 100 faculty responded for the study. The collected data was analyzed using SPSS 20 software with statistical tools such as Chi-square, ANOVAs, at the significance level of 0.05 .
\end{abstract}

KEYWORDS : Institutional Image, Employer Value Proposition, Employee Perception \& Employer Branding

Received: Jul 07, 2020; Accepted: Jul 27, 2020; Published: Aug 11, 2020; Paper Id.: IJHRMRAUG20205

\section{INTRODUCTION}

Employee value proposition are the bundle of benefit an employee seek from the employer in return of various services and contribution made towards the organization. Employee value proposition is fulcrum of a business, with increasing competition to retain best of talent and attract potential candidates those fit the job profile it high time for the companies to introspect on their contribution towards making their organization an ideal place to work. Employers often attempt to follow the best practices prevailing in the industry in order to have a competitive advantage in the form of skill set, but what matters is whether the value proposition offered by the employer are in line with employees expectation. Employee value proposition includes various aspects those are provided to the 
employees such as compensation, benefits, career, work environment, culture etc.

\section{Compensation}

Monetary rewards are one of the driving forces for attracting potential candidates as well as to retain employees in the company. Attractiveness of compensation mainly depends of competitiveness of the employer to pay as per industry standards, ensure financial growth of the employees aligned with company development, timely payment of salary, fair evaluation system in terms of pay hikes after the appraisal process etc.

\section{Benefits}

Companies apart from confining their rewards in the form of salary, also provide other benefits in the form of package which could include educational allowance, flexible working hours, insurance coverage etc.

\section{Career}

With employees these days being from different generation, it's quite challenging for the employer to infer and offer sense of career development to various age group of people which includes generation $\mathrm{X}$, generation Y and millennial. Various researches have shown that career development, opportunity to work in various profile, upgrading skill set, job profile have emerged to be driving force over recent years.

\section{Work Environment and Organization Culture}

Plays a major role in the form of providing a conducive work environment which can be ensured through an open communication system, team work, involving employees in CSR activities, initiative to help employees in balancing their professional and personal life etc.

\section{REVIEW OF LITERATURE}

- Prof. Venkatesh Naga Devaguptapu (2017) Author attempts to elucidate the concept of employer value proposition and how it can help companies to improvise their branding efforts which in turn will help them in talent attraction and retention in the company. study has mainly emphasized on understanding the dimensions of employer branding, impact of employer branding on talent sourcing. The study is based on qualitative research and analysis for the same is based on secondary data of branding practices conducted in various organization and research work done in the area. Based on the outcome of the research it could be inferred that employer value proposition factor such as market reputation of the company, compensation benefits, career growth of employees and other related factors have an impact on talent attraction and sourcing of the organization.

- AvinashPawar (2016) Study objective was to understand employee value proposition and how it can be utilized for branding the employer image. Research is based on the empirical study as employees of Asiatic Manufacturing were chosen as respondents for the study. Author has taken the exit interview database of the company to understand the various reasons for employees to quit their job. Reasons that came into picture were career growth, better job opportunity, change in domain, performance management, rewards and recognition, reporting structure etc.. Based on the outcome of the study, author is of the opinion that company should mainly focus on skill development, training program, competitive pay, career growth of the employees as this would improve the value of employee value proposition offered by the company. 
- Prof. AvinashPawar (2016) Author attempts to explore the impact of employee value proposition on employer branding. Study is based on secondary data of research in the area of employee value proposition and employer branding. research emphasizes on the branding practices of McDonalds, TCS, British Airways, PwC, goggle etc. Researcher states that companies mainly involve into branding to ensure employees are engaged with the organization, are productive at work and also spread a positive word of mouth publicity about the employer. Objective of the study was mainly to emphasize the concept of branding, substantiate the relationship between employee value proposition and employer branding and also the significance of implementing branding for talent attraction and retention. Based on the outcome of the study it can be inferred that EVP and branding are interrelated and will benefit the organization in improving their brand image.

- PratibhaGoswami (2015) Author emphasizes to explore employee value proposition as a key tool for branding the organization and also enhance employer image. The research has adapted a qualitative method as previous survey in the areas of employee value proposition and employer branding have been considered for the study. Based on the outcome of the study it can be observed that Employee value propositionis all about balancing what employees expect from the employer and to what extent employer is able to provide the same in proportion as expected by the manpower. Researcher highlights that EVP can b use as a tool for promoting the company image in condition to the offering made by the employer in the form of training and development, resources, development aspects, career planning, employee centred organization, recreating the workforce which will benefit the company in terms of having a economical employee turnover in the long run.

- AtriSengupta, UmeshBamel, Pankaj Singh (2015) Researcher attempts to understand the influence of value proposition framework of the employer and its influence on external and internal branding of the employer. The research is based on the empirical study as 302 employees from various Indian organizations were chosen for the study. Objective of the research was to understand the value proposition for effective internal and external branding and also the influence of respondents demographics on their expectation of value proposition by the employer. based on the outcome of the study few external branding factors such as image and fundamental values, job structure, work culture, reference values, pride values could be emphasized and for internal branding the employer has to focus on factors such as career potential, employee engagement, comfort vales, esteem values etc. Authors concludes stating that value proposition framework will work as a competitive advantage only when it is in line with the expectation of existing and potential expectation of employees.

- Prof. Avinashpawar*1,Dr.Kuldip S. Charak (2015) Author attempts to emphasize on the concept of employer branding and its importance to various organization in order to attract and retain talented employees in the company. The study is based on the previous research and review of other articles published on the concept of employee value proposition and employer branding. Researcher highlights the need for investing on talent and has given the example of various companies such as Infosys, Tata consultancy services, Tata Steel etc. From the outcome of the research it could be observed that employee value proposition can benefit the organization in internal and external branding, help promote their brand image as a preferred employer by offering the expected benefits by the employees and job seekers in the right proposition.

- Mr. Pankaj Gupta, : Ms. Ruchita Patti, Ms. ShavetaMarwah (2014) Researcher attempts to understand the importance of the concept of employer branding through conceptual review .candidates or pool of talented 
employees come across multiple job opportunities which in turn creates a challenge for employers to retain existing employees and also attract potential candidates in the industry. Major objective of the study was to understand the advantages and limitation of employer branding and the impact of overall reputation of employer. few of the major benefits of practising employer brand as experienced by employer is with reference to recruitment cost, employee attraction and retention at work, increased profitability for the company etc. impact of post implementation of branding is highlighted in the form of minimal time for completion of recruitment process, decreased cost per hire, enriched company values, revenue growth, quality of employees, recruitment etc. based on the outcome of the study author states that independence at work, opportunity to learn at work, organization reputation, working environment, salary package offered by the company plays a crucial role in attracting new candidates and retaining present employees that organization has to focus on.

- HyeJoon Park, Pin Zhou (2013) The author attempts to understand the role of employer branding in enhancing the efficiency of an employer, considers certain factors for the study that influence employees perception of employer and also the relationship between employer branding and employee engagement. Qualitative method was adapted for the study to understand the various factors that influence employer brand image such as talent acquisitions, employee turnover, compensation, organization culture and commitment. Based on the author states that as individual's perception vary similarly the potential employee's preference to organization factors may be different. Companies have to be update themselves on regular basis to understand the industry trends and brand themselves as an attractive employer in the industry. The author also emphasizes on strong relationship between employer branding and employee engagement as the Employee value propositionhas a major influence on employee perception of employer brand.

- Annelize Botha, Mark Bussin, Lukas de Swardt (2011) Author emphasizes on the concept of employer branding and its relevance for the companies for being able to attract and retain talented employees at work. research revolves around the concept of demand for talented employees at work and how pool of talented candidates is observed to be shrinking over the years. Findings of the study are based on secondary information of knowledge of employer branding in the organization and how many companies have been practising the same. Some important factors based on the assumption of this study for employer branding were target group needs, employer value proportion differentiation, people strategy, brand consistency, employer brand communication and employer branding metrics. Based on the outcome of the study it was observed that all the above mentioned factors had a major influence on candidate perception of employer brand. Organization can use employer branding as a strategy by understanding employees expectation from employer and persisting gap. Companies should focus on bridging the gap and providing the expected facilities within organization purview.

\section{RESEARCH GAP}

Based on the articles reviewed for the research it could be observed that studies relating to employee value proposition, employer image have not be conducted in education sector and service sector. The studies conducted in this area are qualitative research and the researchers have indicated the scope for empirical study in the area. Therefore the present research is an empirical study which attempts to understand the influence of employees value proposition on employer image based on the factors such as nature of work, compensation, training and development, work environment, career growth, relationship with manager. 


\section{STATEMENT OF PROBLEM}

Volatile nature in the job market, intense competition in the industry makes it a priority for B Schools to perform or perish. Employee is a key to success for every organization and ability to attract and retain the right talent within the institute is the key to success. With high demand for performing employees in the present scenario, it is proving to be a challenging job to satisfy and retain employees at work. Therefore study attempts to understand various factors, those lead to enhancement of institutional image and suggest an appropriate EVP to be offered in order to be a competitive employer in the industry.

\section{SCOPE OF THE STUDY}

Study is based on the feedback from B Schools employees in Bengaluru region and outcome of the study would be applicable in improving the Employee value proposition of B Schools. Outcome of the study can also be applicable to other companies in service sector and other EVP factors which are not considered for the study can be analyzed for future research with more number of sample sizes in other part of the country.

\section{OBJECTIVE OF THE STUDY}

- To understand the influence of Employee value proposition on the institutional image

- To understand the weightage of each factor considered for the study and its influence employee perception of employer image

- To suggest practices based on employee feedback that will help in enhancing employee perception of employer image

\section{RESEARCH METHODOLOGY}

\section{Research Design}

Descriptive Research was used for the study as it would help to describe the respondents profile and exploratory study was used to phrase the hypothesis for the study.

Sampling Type: Non Probability Sampling

Sampling Technique: convenience sampling

Sample Size: 100

100 B school faculties from Bangalore were chosen as respondents for the study.

Tool: Structured Questionnaire

\section{LIMITATIONS OF THE STUDY}

- Time period for conducting the study was limited, which confines the scope for a detailed research

- As the respondents are chosen as per the researcher convenience and are less in number, they may not be true representative of the population. 


\section{RESEARCH FRAMEWORK}

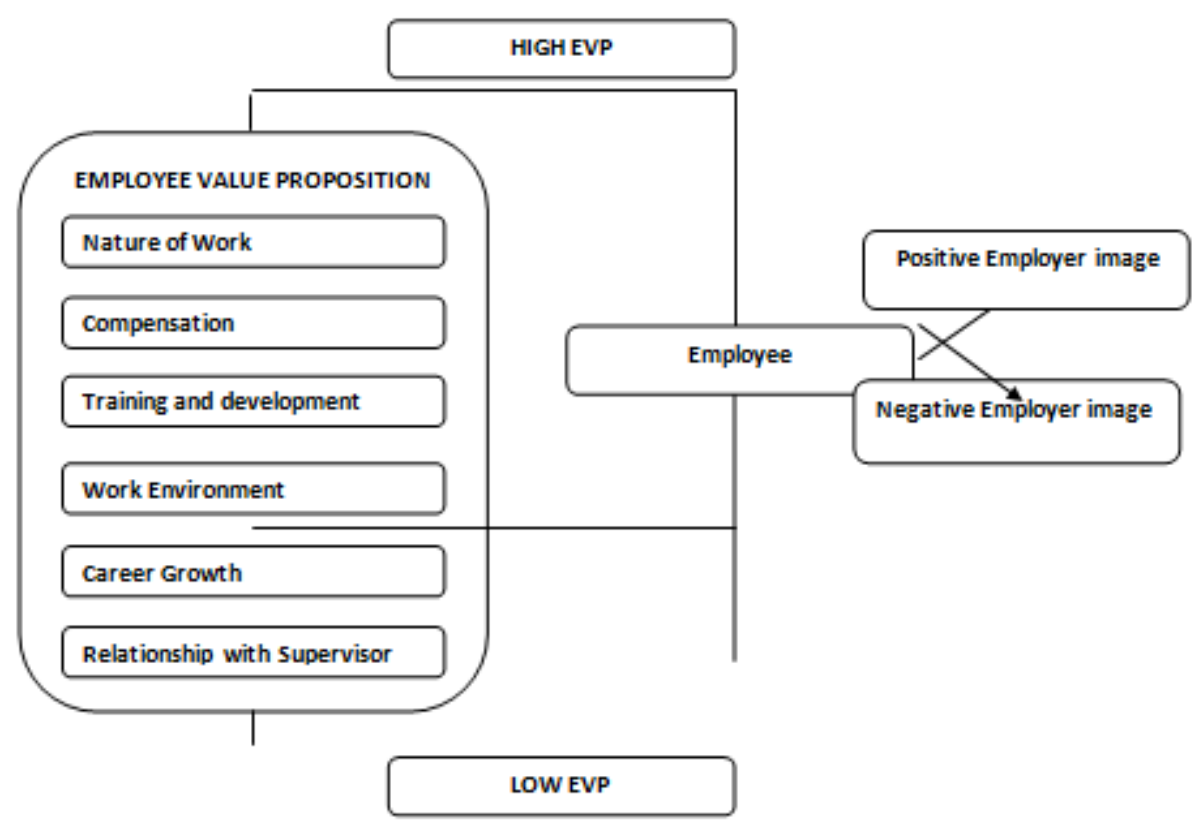

Figure 1.1

\section{DATA ANALYSIS AND INTERPRETATION}

Table 1: Descriptive Statistics

\begin{tabular}{|c|c|c|c|c|c|c|}
\hline & $\mathbf{N}$ & Mean & \begin{tabular}{c|c|} 
Std. \\
Deviation
\end{tabular} & \begin{tabular}{c|} 
Dimension \\
On Mean \\
\end{tabular} & $\begin{array}{l}\text { Dimension on } \\
\text { Std. Deviation }\end{array}$ & RANK \\
\hline $\begin{array}{l}\text { Work performed by me is quite enthusiastic and } \\
\text { challenging in nature ( } \mathrm{N} 1 \text { ) }\end{array}$ & 100 & 1.2800 & .65258 & & & \\
\hline $\begin{array}{l}\text { Institution provides me platform to work on different } \\
\text { profile in my domain ( N } 2 \text { ) }\end{array}$ & 100 & 2.1200 & .85611 & & & \\
\hline $\begin{array}{l}\text { I never face problems related to job stress as nature of } \\
\text { work is interesting ( N } 3 \text { ) }\end{array}$ & 100 & 3.2000 & .86457 & & & \\
\hline $\begin{array}{l}\text { My profile has realistic expectation and never leads to } \\
\text { overburden at work ( N } 4 \text { ) }\end{array}$ & 100 & 2.9100 & 1.27204 & 2.3775 & 0.911325 & $\mathrm{~V}$ \\
\hline $\begin{array}{l}\text { Institution revises employees pay based on work } \\
\text { related performance ( C } 1 \text { ) }\end{array}$ & 100 & 1.9700 & .68836 & & & \\
\hline $\begin{array}{l}\text { Institution pay standards are competitive when } \\
\text { compare with pay in industry ( C } 2 \text { ) }\end{array}$ & 100 & 3.2700 & .76350 & & & \\
\hline $\begin{array}{l}\text { Institution ensures timely payment of salary to } \\
\text { employees at work ( C } 3 \text { ) }\end{array}$ & 100 & 3.8400 & .80050 & & & \\
\hline $\begin{array}{l}\text { Institution ensures transparency in communicating } \\
\text { criteria for pay revision ( C4 ) }\end{array}$ & 100 & 2.2600 & .82413 & 2.835 & 0.769123 & III \\
\hline $\begin{array}{l}\text { Institution conducts training program for all } \\
\text { employees at work ( } \mathrm{T} 1 \text { ) }\end{array}$ & 100 & 3.9700 & .57656 & & & \\
\hline $\begin{array}{l}\text { Content of training and development is based on } \\
\text { training need analysis at work ( T } 2 \text { ) }\end{array}$ & 100 & 2.3000 & .74536 & & & \\
\hline $\begin{array}{l}\text { Training and development imparted to employees is in } \\
\text { line with nature of worked performed ( T } 3 \text { ) }\end{array}$ & 100 & 4.1300 & .41815 & & & \\
\hline $\begin{array}{l}\text { Employees are encouraged to apply skills developed } \\
\text { during training at work ( } \mathrm{T} 4 \text { ) }\end{array}$ & 100 & 1.9000 & 1.07778 & & & \\
\hline $\begin{array}{l}\text { Training imparted to employees are in line with } \\
\text { changing trends in the industry ( T } 5 \text { ) }\end{array}$ & 100 & 2.0100 & 1.29876 & 2.862 & 0.823322 & II \\
\hline
\end{tabular}




\begin{tabular}{|c|c|c|c|c|c|c|}
\hline $\begin{array}{l}\text { Institution accommodates employees with required } \\
\text { resources to perform their work ( W 1 ) }\end{array}$ & 100 & 3.6600 & 1.00725 & & & \\
\hline $\begin{array}{l}\text { Institution encourages work participation management } \\
\text { at work ( W 2 ) }\end{array}$ & 100 & 2.0200 & .56818 & & & \\
\hline Institution treats employees with dignity at work ( W 3 & 100 & 3.3500 & 1.35866 & & & \\
\hline Institution has effective communication system ( W 4 ) & 100 & 1.4600 & .65782 & 2.6225 & 0.897978 & IV \\
\hline $\begin{array}{l}\text { Immediate supervisors counsel employees about their } \\
\text { career growth ( C } 1 \text { ) }\end{array}$ & 100 & 1.4800 & .79747 & & & \\
\hline $\begin{array}{l}\text { Promotion and appraisals in Institution are done to } \\
\text { ensure incremental growth of employee ( C } 2 \text { ) }\end{array}$ & 100 & 2.2300 & .80221 & & & \\
\hline $\begin{array}{l}\text { Institution provides certification program as part of } \\
\text { training and development which helps employees in } \\
\text { better career opportunity ( C 3 ) }\end{array}$ & 100 & 1.3200 & .69457 & 1.676667 & 0.76475 & VI \\
\hline $\begin{array}{l}\text { My supervisor motivates employees to perform better } \\
\text { at work ( R 1 ) }\end{array}$ & 100 & 3.6900 & .87265 & & & \\
\hline $\begin{array}{l}\text { My supervisor provides feedback for appraisal process } \\
\text { based on work performance ( R } 2 \text { ) }\end{array}$ & 100 & 2.5400 & 1.26667 & & & \\
\hline $\begin{array}{l}\text { I share good rapport with my immediate supervisor ( R } \\
\text { 3 ) }\end{array}$ & 100 & 3.8100 & .64659 & 3.346667 & 0.928637 & I \\
\hline I place high value to my employers image & 100 & 2.1100 & 1.42768 & & & \\
\hline $\begin{array}{l}\text { I would rate my employer high on employer value } \\
\text { proposition }\end{array}$ & 100 & 1.9100 & 1.20684 & & & \\
\hline Valid N (listwise) & 100 & & & & & \\
\hline
\end{tabular}

Table 1.2: Ranking Evp Factors Based on Importance

\begin{tabular}{|l|c|c|}
\hline \multirow{2}{*}{ Employer Value Proposition Factors } & \multicolumn{2}{|c|}{ Respondents 100 } \\
\cline { 2 - 3 } & Mean & Rank \\
\hline Relationship with Supervisor & 3.346667 & I \\
\hline Training and development & 2.862 & II \\
\hline Compensation & 2.835 & III \\
\hline Work environment & 2.6225 & IV \\
\hline Nature of work & 2.3775 & V \\
\hline Career growth & 1.676667 & VI \\
\hline
\end{tabular}

From table 1 and 1.1 it can be inferred that academicians give more weightage to relationship with supervisor followed by training and development, compensation, work environment, nature of work and career growth. B schools should focus on building a strong bond between management, department head and employees in the form of employee counselling for their career enhancement; provide inputs to staff on areas of improvement and strategy for better career development. employee counselling will create a conducive environment at workplace which not only help in their improvement in performance but also pave directions for career development which will result in better compensation of an efficient and performing employee.

\section{HYPOTHESIS}

\section{HYPOTHESIS 1}

- HO : there is no association between employees work experience and their perception of being treated with dignity at work

- HA : there is association between employees work experience and their perception of being treated with dignity at work 
Table 2: ANOVA

\begin{tabular}{|l|c|c|c|c|c|}
\hline \multicolumn{6}{|c|}{ B Schools Treats Employees with Dignity at Work } \\
\hline & Sum of Squares & df & $\begin{array}{c}\text { Mean } \\
\text { Square }\end{array}$ & F & Sig. \\
\hline Between Groups & 37.237 & 4 & 9.309 & $6.078 * * .000$ \\
\hline Within Groups & 145.513 & 95 & 1.532 & & \\
\hline Total & $\mathbf{1 8 2 . 7 5 0}$ & $\mathbf{9 9}$ & & & \\
\hline
\end{tabular}

From table number 2 it can be inferred that there is association between employees work experience and their perception of being treated with dignity at work as ( $\mathrm{P}$ Value is $=.000<0.01$ )

\section{HYPOTHESIS 2}

- $\quad \mathrm{HO}$ : there is no association between work experience of the employee and his or her perception training provided being related to work

- HA : there is association between work experience of the employee and his or her perception training provided being related to work

Table 2.1: ANOVA

\begin{tabular}{|l|c|c|c|c|c|}
\hline \multicolumn{6}{|c|}{ Training and Development Imparted to Employees is in Line with Nature of Worked Performed } \\
\hline & Sum of Squares & df & Mean Square & F & Sig. \\
\hline Between Groups & 1.720 & 4 & .430 & 2.620 & $* .040$ \\
\hline Within Groups & 15.590 & 95 & .164 & & \\
\hline Total & $\mathbf{1 7 . 3 1 0}$ & $\mathbf{9 9}$ & & & \\
\hline
\end{tabular}

From the above table it can be interpreted that there is association between work experience of the employee and his or her perception training provided being related to work as $(\mathrm{P}=0.040<0.05)$

\section{HYPOTHESIS 3}

- H0: there is no association between employee having an opportunity to perform different job profile and employee rating employer high on EVP

- HA: there is association between employee having an opportunity to perform different job profile and employee rating employer high on EVP

Table 3: Crosstab

\begin{tabular}{|c|l|c|c|c|c|c|}
\hline \multicolumn{2}{|c|}{} & \multicolumn{2}{|c|}{ I would Rate my Employer high on Employer Value } \\
Proposition
\end{tabular}




Chi-Square Tests
\begin{tabular}{|l|c|c|c|}
\hline & Value & Df & Asymp. Sig. (2-Sided) \\
\hline Pearson Chi-Square & $26.481^{\mathrm{a}}$ & 16 & $* .048$ \\
\hline Likelihood Ratio & 22.609 & 16 & .125 \\
\hline Linear-by-Linear Association & .090 & 1 & .764 \\
\hline N of Valid Cases & 100 & & \\
\hline
\end{tabular}

From the above table it can be observed that there is association between employee having an opportunity to perform different job profile and employee rating employer high on EVP as $(\mathrm{P}=0.048<0.05)$

\section{HYPOTHESIS 4}

- $\mathrm{HO}$ : there is no association between employees being paid based on performance and employees rating their employer high on EVP

- HA : there is association between employees being paid based on performance and employees rating their employer high on EVP

Table 3.1: Crosstab

\begin{tabular}{|c|c|c|c|c|c|c|c|}
\hline \multicolumn{8}{|c|}{ Count } \\
\hline & & \multicolumn{5}{|c|}{$\begin{array}{l}\text { I would Rate my Employer High on Employer Value } \\
\text { Proposition }\end{array}$} & \multirow{2}{*}{ Tota } \\
\hline & & $\begin{array}{l}\text { Strongly } \\
\text { Disagree }\end{array}$ & Disagree & $\begin{array}{l}\text { Neither Agree } \\
\text { nor Disagree }\end{array}$ & Agree & $\begin{array}{l}\text { Strongly } \\
\text { Agree }\end{array}$ & \\
\hline \multirow{4}{*}{$\begin{array}{l}\text { Organization revises employees pay } \\
\text { based on work related performance }\end{array}$} & $\begin{array}{l}\text { Strongly } \\
\text { disagree }\end{array}$ & 15 & 1 & 2 & 1 & 2 & 21 \\
\hline & Disagree & 34 & 17 & 8 & 1 & 5 & 65 \\
\hline & $\begin{array}{l}\text { Neither agree } \\
\text { nor disagree }\end{array}$ & 3 & 4 & 3 & 0 & 0 & 10 \\
\hline & Agree & 0 & 1 & 1 & 2 & 0 & 4 \\
\hline \multicolumn{2}{|l|}{ Total } & 52 & 23 & 14 & 4 & 7 & 100 \\
\hline
\end{tabular}

\begin{tabular}{|l|c|c|c|}
\hline \multicolumn{3}{|c|}{ Chi-Square Tests } \\
\hline & Value & Df & Asymp. Sig. (2-Sided) \\
\hline Pearson Chi-Square & $35.516^{\mathrm{a}}$ & 12 & .000 \\
\hline Likelihood Ratio & 25.283 & 12 & .014 \\
\hline Linear-by-Linear Association & 3.176 & 1 & .075 \\
\hline N of Valid Cases & 100 & & \\
\hline
\end{tabular}

From the above table it can be inferred that there is association between employees being paid based on performance and employees rating their employer high on $\mathrm{EVP}$ as $(\mathrm{P}=.000<0.01)$

\section{HYPOTHESIS 5}

- H0: there is association between employees sharing a good rapport with their employer and employees placing high value to their employer image

- HA: there is association between employees sharing a good rapport with their employer and employees placing high value to their employer image 
Table 3.3: Crosstab

\begin{tabular}{|c|c|c|c|c|c|c|c|}
\hline \multicolumn{8}{|c|}{ Count } \\
\hline & & \multicolumn{5}{|c|}{ I Place High Value to my Employers Image } & \multirow[b]{2}{*}{ Total } \\
\hline & & $\begin{array}{l}\text { Strongly } \\
\text { Disagree }\end{array}$ & Disagree & $\begin{array}{c}\text { Neither Agree nor } \\
\text { Disagree }\end{array}$ & Agree & $\begin{array}{l}\text { Strongly } \\
\text { Agree }\end{array}$ & \\
\hline \multirow{3}{*}{$\begin{array}{l}\text { I share good rapport with my } \\
\text { immediate supervisor }\end{array}$} & $\begin{array}{l}\text { Neither agree nor } \\
\text { disagree }\end{array}$ & 17 & 3 & 3 & 5 & 4 & 32 \\
\hline & Agree & 28 & 15 & 5 & 4 & 3 & 55 \\
\hline & Strongly agree & 6 & 2 & 0 & 0 & 5 & 13 \\
\hline \multicolumn{2}{|l|}{ Total } & 51 & 20 & 8 & 9 & 12 & 100 \\
\hline
\end{tabular}

Chi-Square Tests

\begin{tabular}{|l|c|c|c|}
\hline & Value & Df & Asymp. Sig. (2-sided) \\
\hline Pearson Chi-Square & $17.154^{\mathrm{a}}$ & 8 & $* .029$ \\
\hline Likelihood Ratio & 17.084 & 8 & .029 \\
\hline Linear-by-Linear Association & .113 & 1 & .737 \\
\hline N of Valid Cases & 100 & & \\
\hline
\end{tabular}

From the above table it can be interpreted that there is association between employees sharing a good rapport with their employer and employees placing high value to their employer image as $(\mathrm{P}=0.029<0.05)$

\section{SUGGESTIONS}

- Employees should be put on job rotation in their domain so that they will be able to equip themselves in various roles and it would facilitate continuous learning for employee. It would enhance employee's versatility to perform multiple tasks, making it easy for the B Schools for employee replacement during the process of man power planning.

- Additional role and responsibility of the employees should be backed with related rewards, recognition and increase in pay, without which employee will sense overburden at work which will de-motivate him and deteriorate his performance at work

- B Schools should encourage practices such as workers participation in management, open communication system, management by objective which will develop sense of involvement among employees in every decision taken by the management and personnel's will work with more interest as it is a collective decision which has been implemented at work.

- B Schools should provide training to employees as per the recent trends prevailing in their area of specialization, it will not only enhance employee engagement with the employer but the quality of education imparted by the academicians would be at par with industry standards.

- Superior subordinate relation has emerged as an important factor in the study, B schools should mentor their employees for career growth, management and department heads should take initiative for career planning of their employees which will yield good return in the form of incremental development in B Schools Research and development.

\section{CONCLUSIONS}

Organization in the present scenario initiates efforts toimprove quality their Employer value proposition. Major reason for 
organization being employee centred is due to increased demand for quality workforce in the job market, which instigates employees to look for better job avenues in other organization. EVP of the B Schools which includes work conditions reward and pay policies, leave facility, flexibility at work place play a major role in ensuring employee perception about employer image. With changing industry practices and thrust for productive employees it is become extremely important for the B Schools to not just frame the policies but at the same time understand satisfaction of workforce towards these policies. Employee satisfaction is extremely important with human resources practices being extremely competitive in the market with specific focus on attracting and retaining workforce in the B Schools. Although B Schools thrive to update their policies on continuous basis it is important to understand to what extent they are able to meet employee's expectation. On a conclusive note I would like to state that B Schools should change process of centralized decision making system to recent practices such as workers participation in management, management by objective which will increase employee's involvement right from planning to execution stage. B Schools should also focus on employee development in terms of providing exposure related various task performances at work and at the same time improve its rewards and recognition system by providing priority to efficient performing employees at which would result in talent attraction and retention.

\section{REFERENCS}

1. Prof. Venkatesh Naga Devaguptapu ( 2017 ) Framework for integrating - employer branding and talent sourcing International Journal of Advanced Scientific Research \& Development Vol. 04, Iss. 01, Ver. I, Jan" 2017, pp. 33 - 39

2. AvinashPawar ( 2016 ) Study on Employee Value Proposition for Emerging Employer Brand: Case of Asiatic Manufacturing ISSN (Print): 2319-5479, Volume-5, Issue-1, 2016

3. OuadaJamoussi, Hanene Ben, and EmnaMakhloufMakhlouf. "School Performance and the Education Systems' Efficiency: An International Comparison Based on OECD PISA Surveys." International Journal of Human Resources Management (IJHRM) $\operatorname{ISSN}(P)$ (2018): 2319-4936.

4. Prof. AvinashPawar ( 2016 ) Employee Value Proposition: A Collaborative Methodology for Strengthening Employer Brand Strategy Journal of Resources Development and Management, ISSN 2422-8397 An International Peer-reviewed Journal

5. PratibhaGoswami ( 2015 ) Employee Value Proposition: A Tool for Employment Branding International Journal of Scientific and Research Publications, Volume 5, Issue 12, December 2015263 ISSN 2250-3153

6. Izobo-Martins, O., O. A. Dare-Abel, and Kunle Ayo-Vaughan. "Infrastructure Conditions in Public Secondary Schools, Ogun State, Nigeria." Journal of Civil, Structural, Environmental and Infrastructure Engineering Research and Development 4.5 (2014): 17-25.

7. AtriSengupta,UmeshBamel, Pankaj Singh ( 2015 ) value proposition framework : implications for employer branding Springer decision December 2015, 42(3):307-323 DOI 10. 1007/s40622.015.0097-x

8. Prof. Avinashpawar*1, Dr.Kuldip S. Charak ( 2015 ) Employee value proposition leading to employer brand: The Indian organizations outlook international journal of management research \& review ISSN : 2249-7196 IJMRR/dec. 2015/volume 5/issue 12/article no-11/1195-1203

9. Goli, BR. "Application of Cooperative Learning in Teaching English as a Second or Foreign Language and its Effects in Indian Schools." International Journal of English and Literature (2015).

10. Mr. Pankaj Gupta, ( 2014 ) : Ms. Ruchita Patti, Ms. ShavetaMarwah, Employer branding : A descriptive study, International Journal of Economic and Management Strategy. ISSN 2278-3636 Volume 4, Number 1 (2014), pp. 1-10 
11. HyeJoon Park, Pin Zhou (2013 ) Is There a Correlation for Companies With a Strong Employment Brand Between Employee Engagement Levels and Bottom Line Results

12. Reddy, E. Lokanadha, and S. H. A. I. K. Karim. "Service Quality and Student Satisfaction A Case Study in Private management institutions in Chittor district of Andhra Pradesh." International Journal for Human Resource Management and Research 4.2 (2014): 1-8.

13. Annelize Botha, Mark Bussin, Lukas de Swardt ( 2011 ) An employer brand predictive model for talent attraction and retention, AOSIS Received: 03 June 2011 Accepted: 15 Sept. 2011 Published: 14 Nov. 2011

\section{REFERENCE WEBSITE}

- $\quad$ http://www.ijsrp.org/research-paper-1215/ijsrp-p4839.pdf

- https://www.ripublication.com/jems/jemsv4n1_01.pdf

- https://core.ac.uk/download/pdf/54184793.pdf

- https://www.researchgate.net/publication/281489607_Value_proposition_framework_implications_for_employer _branding

- https://pdfs.semanticscholar.org/46c2/b8aaf0af1c4d87624ae6b6b6b54687b49728.pdf

- http://www.irdindia.in/journal_ijrdmr/pdf/vol5 iss1/6.pdf

- https://www.gim.ac.in/newpdfs/Framework-for-Integrating\%E2\%80\%93Employer-Branding-\&-Talent$\underline{\text { Sourcing.pdf }}$

- https://www.talentlyft.com/en/blog/article/105/employee-value-proposition-evp-magnet-for-attracting-candidates 